\title{
MODELLING THE STRUCTURE OF TERRESTRIAL LANDSCAPES IN URBAN AREAS
}

\author{
NATALYA KRUTSKIKH \\ Institute of Geology, Karelian Research Center, Petrozavodsk, Russia
}

Manuscript received: December 17, 2020

Revised version: January 19, 2021

\begin{abstract}
KRUTSKIKH N., 2021. Modelling the structure of terrestrial landscapes in urban areas. Quaestiones Geographicae 40(1), Bogucki Wydawnictwo Naukowe, Poznań, pp. 39-49. 2 tables, 13 figs.

ABSTRACT: The study of internal and external factors in the formation of an urban geosystem is determined by its complex structure and multiple connections. Based on geoinformation modelling, an analysis of the landscape structure of the city territory is carried out, which can be a basis for further geoecological research. Morphometric indicators, which make it possible to determine the elementary geochemical landscapes, are indicated according to the data of the digital elevation model. A standardised topographic position index (TPI) is used to determine locations. Spatial zoning according to the type of land use reflects the qualitative features of the external load and technogenic impact. The data on the composition of the lithogenic base show the properties of the depositing medium and determine the natural background. Number of categories of landscapes identified are 58, characterised by a homogeneous geological composition, technogenic load and conditions for the migration of matter. The ratios of various landscape zones have been calculated. The study area as a whole is characterised by the predominance of migration processes over accumulation.
\end{abstract}

KEYWORDS: DEM, landscape structure, spatial modelling, terrestrial landscapes of urban areas

Corresponding author: Natalya Krutskikh;natkrut@gmail.com

\section{Introduction}

Urban territories are complex multicomponent systems. The factors that determine and form the geosystem of the city are different and diverse. They are divided into internal (natural) and external (artificial) factors, and they are caused by human activity. Geological structure, climate, relief, soils describe the internal features of the geosystem formation. Technogenic factors have a complex structure and include production processes and their derivatives, household, cultural, and social relations. Human is the central link of the city system and on the one hand, acts as a powerful transformative force; while on the other hand, it is a vulnerable part and an ecological target.
During economic activity, elements and compounds are often take part in geochemical cycles that are often uncharacteristic for these territories or in concentrations unusual for them. The migration of elements is determined by various factors, in which the morphological structure of the territory occupies a special position (Jones et al. 2008). The relief plays an important role in the lateral transfer of matter and energy and is the most important factor in the spatial distribution of landscapes (Novakovsky, Permyakov 2019). In the theory of geochemical landscapes, the following types of elementary landscapes (EL) are differentiated eluvial, super-aquatic, sub-aquatic, as well as transeluvial landscapes of slopes, trans-accumulative landscapes of the lower 
parts of slopes, accumulative-eluvial landscapes of closed depressions on watershed surfaces (Polynov 1952, Glazovskaya 1988).

With the development of geoinformation technologies, it has become possible to use remote sensing data (Krenke, Puzachenko 2008) and global digital elevation models (Novakovsky et al. 2007) widely to create a landscape basis. The modern literature provides research data on the automated identification of landscape units (Drăgut,, Blaschke 2006, Mkrtchyan 2006, Klingseisen et al. 2008, Piloyan, Konečný 2017) and their use as a fundamental basis for geochemical prospecting (Sokolov, Yurchenko 2010), ecological and geochemical research (Vlasov et al. 2017). The main basic concepts of geomorphometry are extensively described in the literature (Shary et al. 2002, Evans 2012, Florinsky 2012). The distinguishing of elementary landscapes is based on morphometric parameters of the relief such as slope steepness, surface curvature and location. A number of works have revealed the effective results of using the topographic position index (TPI) method for mapping relief elements and identifying positive and negative forms. The method was tested within the high-mountainous relief (Weiss 2001, Mokarram, Seif 2014), lowland and high mountain areas (Zwoliński, Stefańska 2015), erosional and karst relief (Tagil, Jenness 2008) and various regions of Crimea (Tokarev, Roshchina 2015).

The complexity of the structure of the city's geosystem determines the specific features of creating landscape models necessary for a qualitative study of the geoecological state of the urban environment and analysis of the geochemical features of the territory. The landscape model makes it possible to assess the environmental risks of pollution, identify key areas for detailed research, switch to an irregular network of geochemical sampling and reduce the number of sampling points.

The paper analyses the landscape structure and creates a landscape basis for an urban area, reflecting the external and internal factors of geochemical migration. The main points of the study are:

- distinguishing elementary landscapes that characterise lateral migration,

- study of the spatial differentiation of the lithogenic base, reflecting, on the one hand, the composition of the natural component, and , the sorption properties of the depositing medium on the other hand and

- analysis of the functional use of territories as an indicator of the types and characteristics of external impact on the natural environment.

\section{Study area}

The place of the research is the territory of the Petrozavodsk city district. The city of Petrozavodsk is located in the northwest of the Russian Federation, on the shores of Lake Onega (Fig. 1). The coordinates of the city centre are

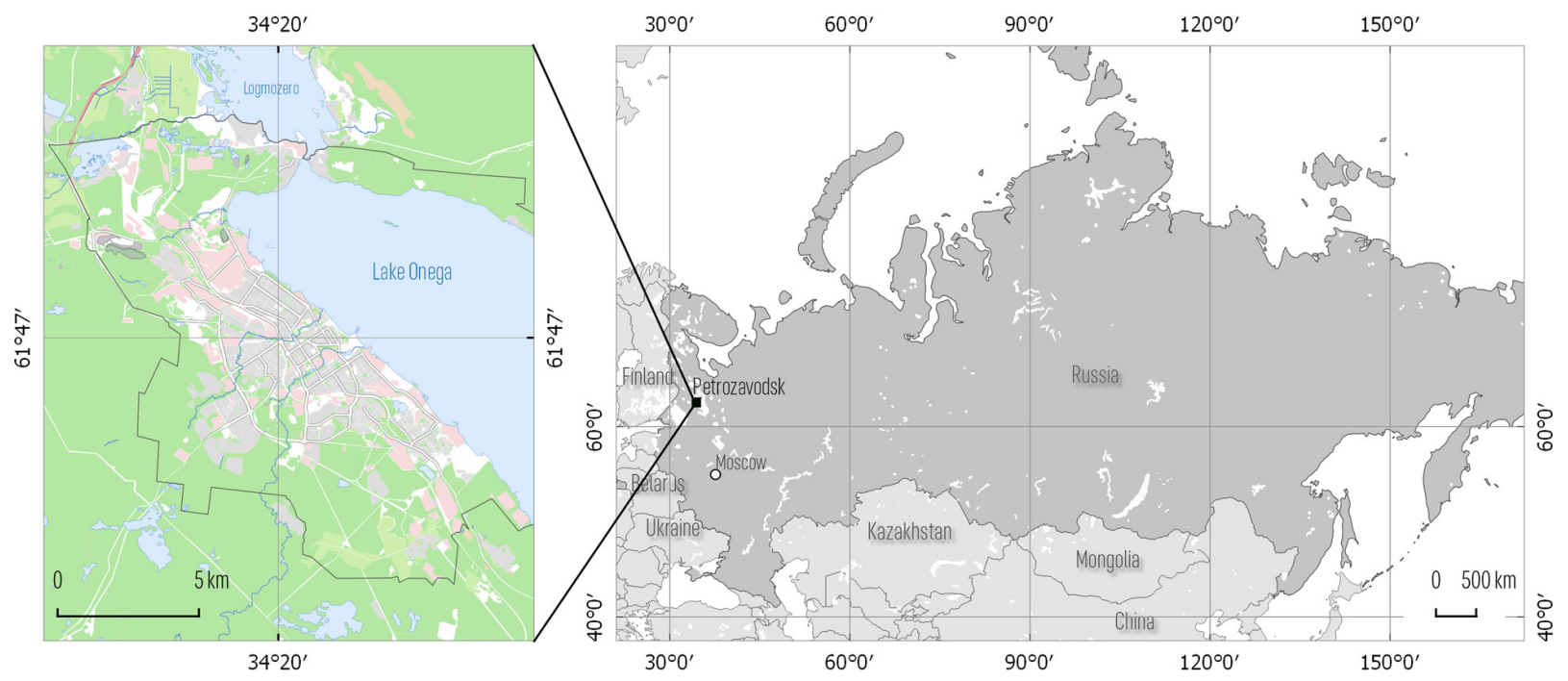

Fig. 1. Location of the research area. 
$61^{\circ} 47^{\prime} \mathrm{N}, 34^{\circ} 20^{\prime} \mathrm{E}$. The area of the city is $135 \mathrm{~km}^{2}$. The population is about 280,000 people. The city is stretched along the Petrozavodsk Bay of Lake Onega from northwest to southeast for almost $25 \mathrm{~km}$. The modern relief of Petrozavodsk was formed due to the impact of the last Late Valdai Scandinavian glaciation. The relief of the city is medium hilly with a range of absolute elevations from $33 \mathrm{~m}$ (the level of Lake Onega) to $180.4 \mathrm{~m}$. The highest elevations are located in the eastern and south-eastern parts of the city. There are four flat terraces on the coastal slope, gradually lowering towards the lake. On the north-eastern coast of the Petrozavodsk Bay of Lake Onega, there is a denudation-tectonic ridge composed of volcanic-sedimentary rocks. The maximum absolute marks here are $122.9 \mathrm{~m}$.

The man-made load on the environment in the city is generated to the development of wood-processing and food industry, construction areas, the motor vehicle fleet that has grown exponentially in recent years and actively developed territories.

Earlier, ecological studies aimed at studying the geochemical features of natural environments were carried out here (Krutskikh, Kosinova 2014, Novikov 2015, Krutskikh et al. 2016). Ecological and geochemical studies of soils were carried out based on a regular sampling network without taking into account of the detailed landscape characteristics. The creation of a landscape structure model will make it possible to interpret geochemical information qualitatively, determine possible emissions in a sample of geochemical data, and also designate the most informative polygons for setting up regular ecological monitoring.

\section{Initial data}

The digital elevation model (DEM) is taken from the original project of De Ferranti (2014) (Fig. 2). DEM was obtained by digitising topographic maps at a scale of 1:100,000.

The accuracy of the digital elevation model within the study area was verified by comparing the DEM with control points obtained from a topographic map at a scale of 1:100,000, the following statistical indicators were used for comparing them: mean absolute error (MAE), root mean square error (RMSE) and standard deviation (SD) (Szypuła 2019). Statistical parameters are presented in Table 1.

The analysis of the geological structure was carried out based on the study of Quaternary deposits and also on the basis of the international map Quaternary deposits of Finland and the NorthWest of the Russian Federation and their raw materials. The map reflects the achievements in the study of the geological structure, material composition of Quaternary deposits and geomorphology of the region (Quaternary deposits 1993). The initial map of Quaternary deposits is based on the

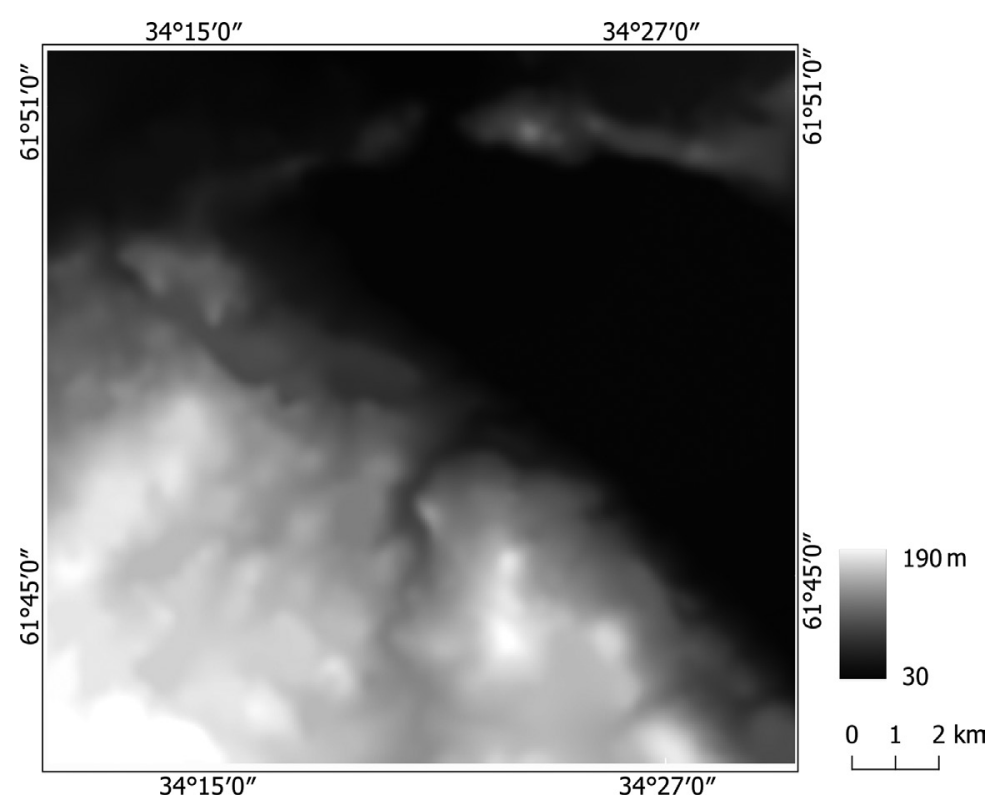

Fig. 2. Digital elevation model of Petrozavodsk. 
Table 1. Results of assessing the accuracy of DEM by control points.

\begin{tabular}{|l|c|}
\hline \multicolumn{1}{|c|}{ Parameter } & Value $[\mathrm{m}]$ \\
\hline Minimum & -3.6 \\
\hline Maximum & 11.4 \\
\hline MAE & 3.5 \\
\hline RMSE & 5.4 \\
\hline SD & 4.4 \\
\hline
\end{tabular}

lithological (sedimentological) principle - different genetic types of Quaternary deposits are distinguished, differing in material composition.

Functional zoning of the territory is based on decoded data from high-resolution satellite images. The initial data are satellite images from Google, Landsat and Sentinel.

\section{Methods}

The main stages of creating a landscape base are shown in Figure 3. SAGA and QGIS software were used for calculations and constructions.

\section{Distinguishing elementary landscapes}

The aim of DEM preprocessing is to eliminate noise. The most important task is the selection of parameters that allow transforming the model without losing any detail. Smoothing of the original model was carried out using the simple filter module, based on the mean square deviation. The most optimal anti-aliasing turned out to be a floating window with a radius of $3 \mathrm{px}$. The hydrological correction of the model was carried out using the fill sinks module (Planchon, Darboux 2002). The method consists of filling the surface with a layer of water, which is then removed to fill the depressions.
The solution to the problem of identifying relief elements is carried out based on a morphometric indicators analysis. The following attributes were obtained from DEM using the SAGA program: TPI, slope and curvature.

The method for determining TPI is based on finding the difference between the value of the cell height and the value of the average height of a given environs surrounding that cell (Weiss 2001). Positive TPI values correspond to uplands, ridges, hills. Negative TPI means lowlands, valleys, ravines and basins. Cells with TPI values close to zero correspond to flat areas or midslopes. It should be noted that the method has limitations to use in heterogeneous relief structure with high roughness (De Reu et al. 2013). The solution to such problems is obtained by standardising TPI values (Gallant, Wilson 2000). The standardisation of values allows the classification of TPIs. Weiss (2001) suggests to use the following categorisation scheme for relief elements:

- Valley: TPI $\leq-1$ SD,

- Lower slope: $-1 \mathrm{SD}<\mathrm{TPI} \leq-0.5 \mathrm{SD}$,

- Flat area: $-0.5 \mathrm{SD}<\mathrm{TPI}<0.5 \mathrm{SD}$, slope $\leq 5^{\circ}$,

- Middle slope: $-0.5 \mathrm{SD}<\mathrm{TPI}<0.5 \mathrm{SD}$, slope $>5^{\circ}$,

- Upper slope: 0.5 SD $<$ TPI $\leq 1$ SD, and

- Ridge: TPI $>1$ SD.

The dimension of the environs is a determining factor for calculating the index and it is determined by the scale and objectives of the study.

The angle of surface inclination is an important parameter for determining landscape characteristics. The slope of the surface determines the surface runoff and drainage, the rate of material drift, erosion processes, and the thickness of the soil profile. The slope of the surface is the angle between the horizontal plane and the tangent to the earth's surface. The following scheme was used to classify slopes (Zhuchkova, Rakovskaya 2004):

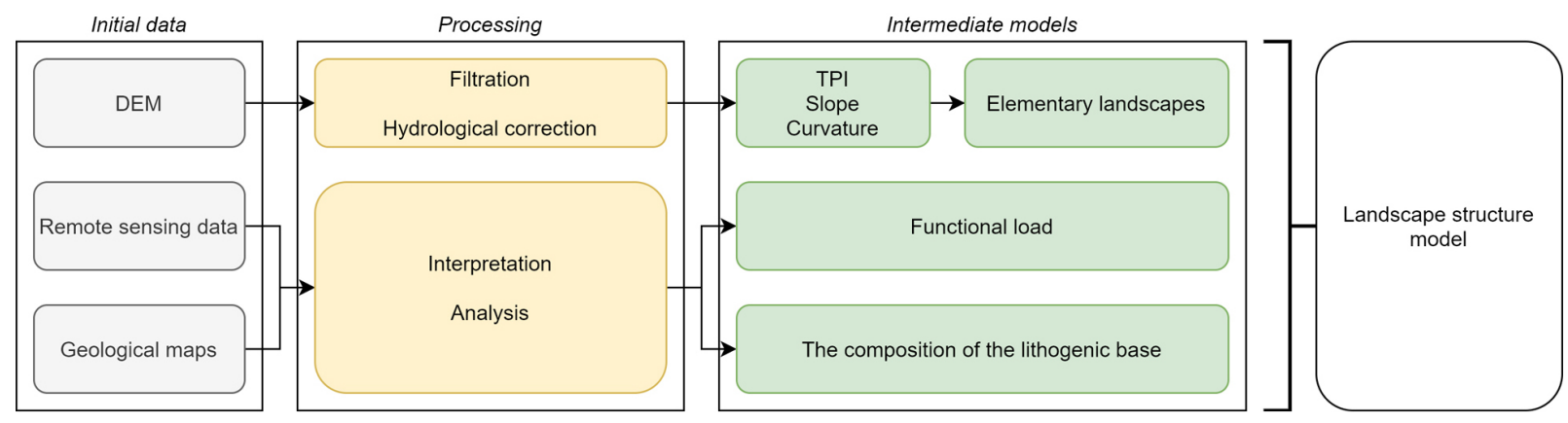

Fig. 3. Scheme of creating a model of landscape structure. 
- $<1^{\circ}$ - flat (sub-horizontal) plains,

- $1-3^{\circ}$ - very gentle slopes,

- $3-5^{\circ}$ - gentle slopes (sloping planes),

- 5-7 - sloppy slopes,

- $7-10^{\circ}$ - sloping slopes, and

- $10-15^{\circ}$ - strongly sloping slopes.

The curvature of the relief represents the concavity and convexity of the surface and determines the type of accumulation mechanism (Shary et al. 2002). Total curvature is the cumulative measure of the curvature of the earth's surface. The positive values of curvature describe convex areas (areas of transit of matter), while negative values describe concave areas (accumulation).

\section{Functional organisation of the territory}

Functional zoning is a process of identifying areas that are relatively homogeneous in terms of technogenic load. The zonation is based on the author's interpretation of decoded high-resolution satellite images. Within the city, the following types of functional use are distinguished: industrial, residential, recreational, agricultural and special. Industrial zones include territories within which enterprises of various types of industry and storage facilities are predominantly distributed. Territories with a predominance of residential buildings determine the predominantly residential type of functional use. Recreational areas include green spaces. The use of territories for growing crops, reclamation zones determine the agricultural type. The special zone includes zones used as restricted areas, as well as cemeteries.
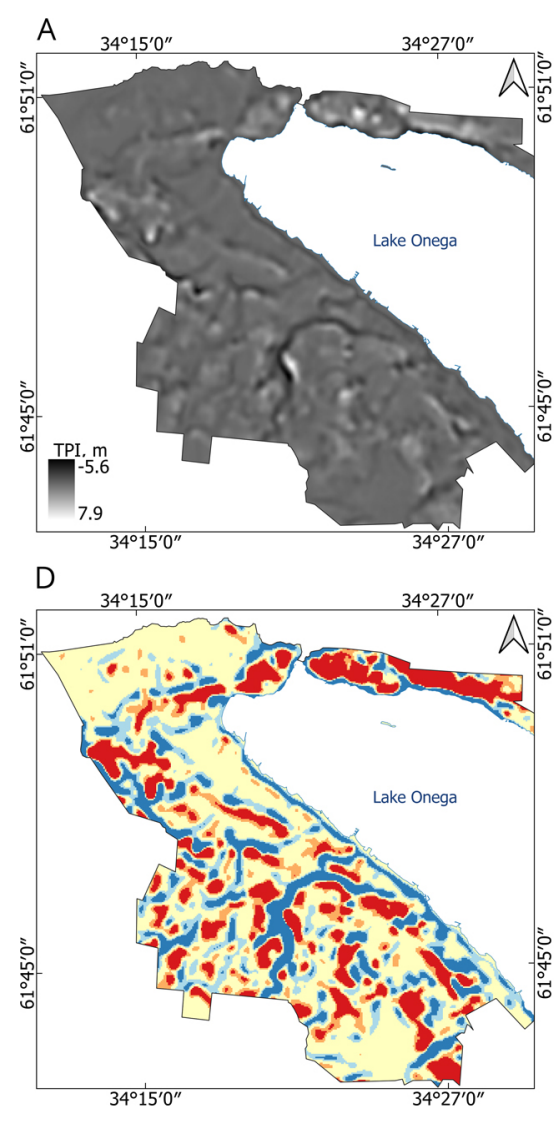

depressions, drainage lowlands $(\mathrm{TPI}<=-1 \mathrm{SD})$ $\square$ upper slopes $(0.5 \mathrm{SD}<\mathrm{TPI}<1 \mathrm{SD})$

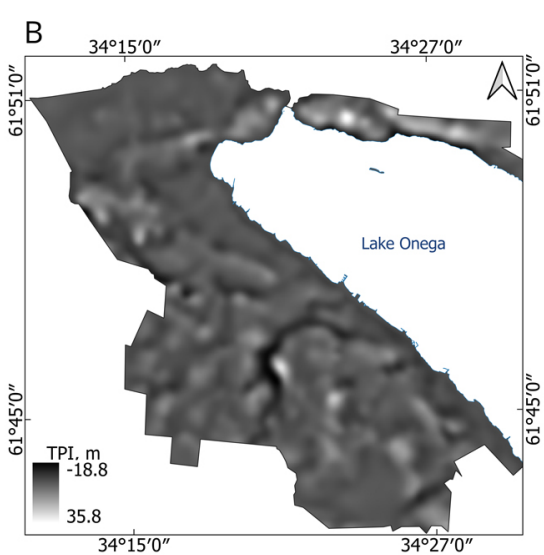

E

\section{Results and discussion}

\section{Distinguishing elementary landscapes}

The calculation of the topographic index and standardised TPI was carried out for three sizes 
of the radius of the environs: $200 \mathrm{~m}, 500 \mathrm{~m}$ and $1000 \mathrm{~m}$ (Fig. 4). Further, the amplitude of the TPI values is $13 \mathrm{~m}, 55 \mathrm{~m}$ and $90 \mathrm{~m}$ for the radius of the environs of $200 \mathrm{~m}, 500 \mathrm{~m}$ and $1000 \mathrm{~m}$, respectively (Fig. 4A-C). The size of the window should correspond to the smallest discernible landform (Zwoliński, Stefańska 2015). A large radius was used to map large landforms and reduce noise. Locating using a radius of $1000 \mathrm{~m}$ displays large landforms without considering the local changes (Fig. 4F). Using the $200 \mathrm{~m}$ radius of the environs allows highlighting small relief elements. But the detail of the digital elevation model, based on which the construction is carried out, corresponds to a scale of 1:100,000 and these elements may turn out to be false. The following relief elements are distinguished according to the standardised TPI:

- tops of hills and highlands,

- upper slopes,

- gentle slopes,

- lower slopes,

- depressions and drainage lowlands.

Any increase in the radius of the environs changes the territory classification mainly due to a decrease in the area of flat areas (Fig. 5). Visual analysis of the data obtained showed that the environs radius equal to $500 \mathrm{~m}$ is the most optimal for medium-scale mapping of the urban area. All further calculations are carried out on this basis.

The study of the slope steepness revealed that within the city, the angles of inclination are mainly up to $5^{\circ}$ (the slopes are gentle and very gentle). And only $3 \%$ of the territory has a slope of $5-10^{\circ}$. No slopes over $10^{\circ}$ were found (Fig. 6). Gentle slopes and sloppy slopes are presented in the north-east of the city, where neotectonic deformations take place. The study of the curvature

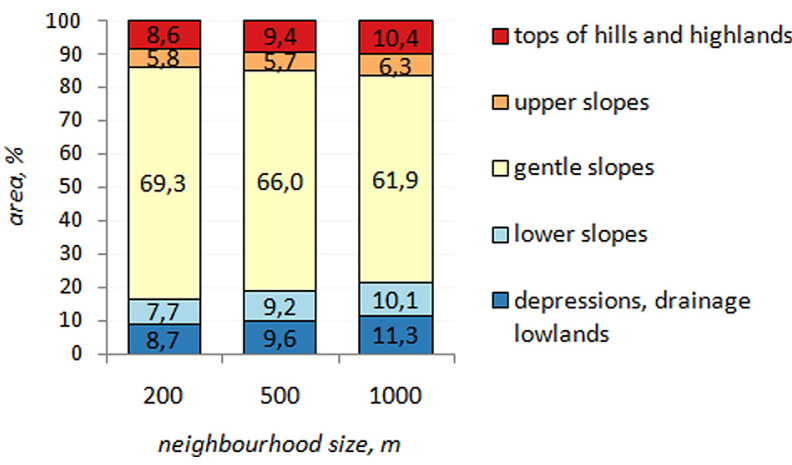

Fig. 5. The ratio of relief classes when changing the estimated radius of the environs.

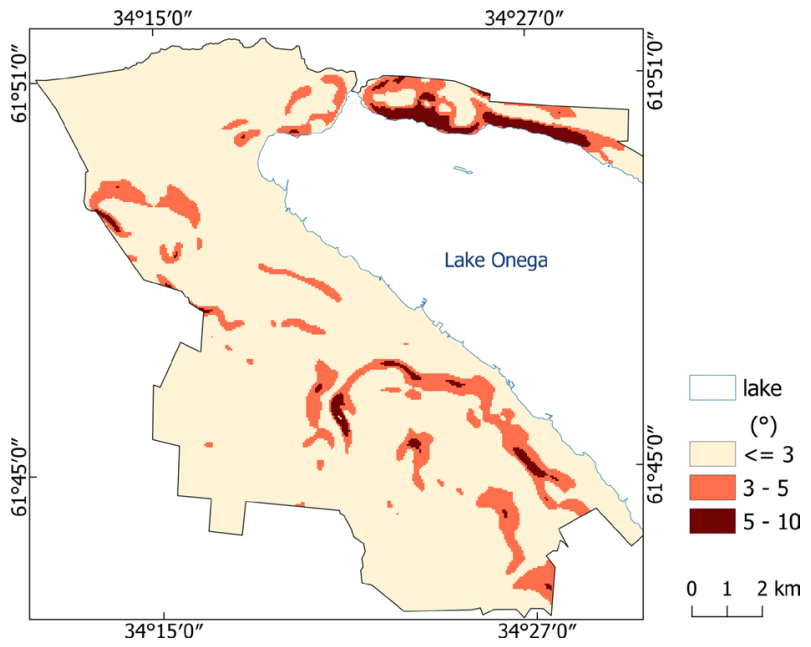

Fig. 6. Map of slope.

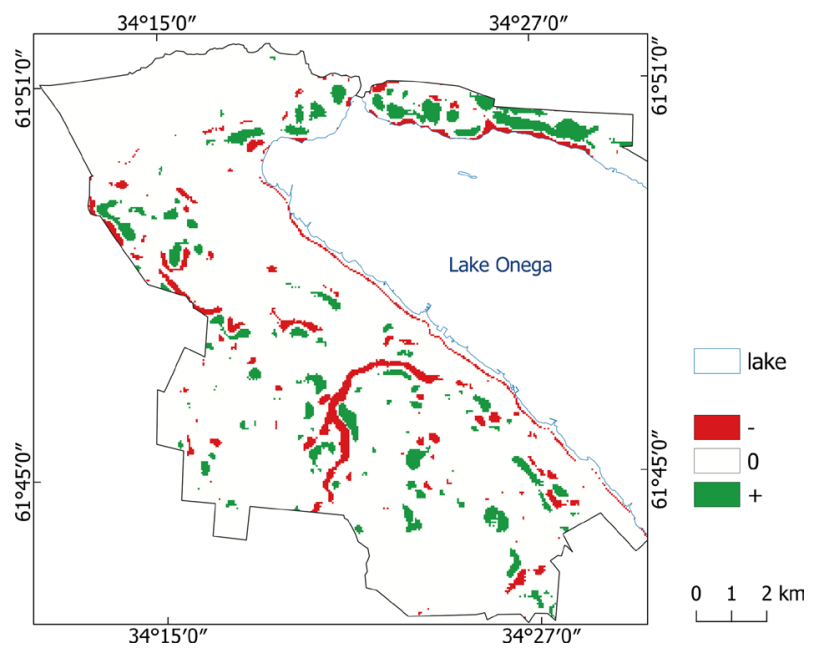

Fig. 7. Map of general curvature.

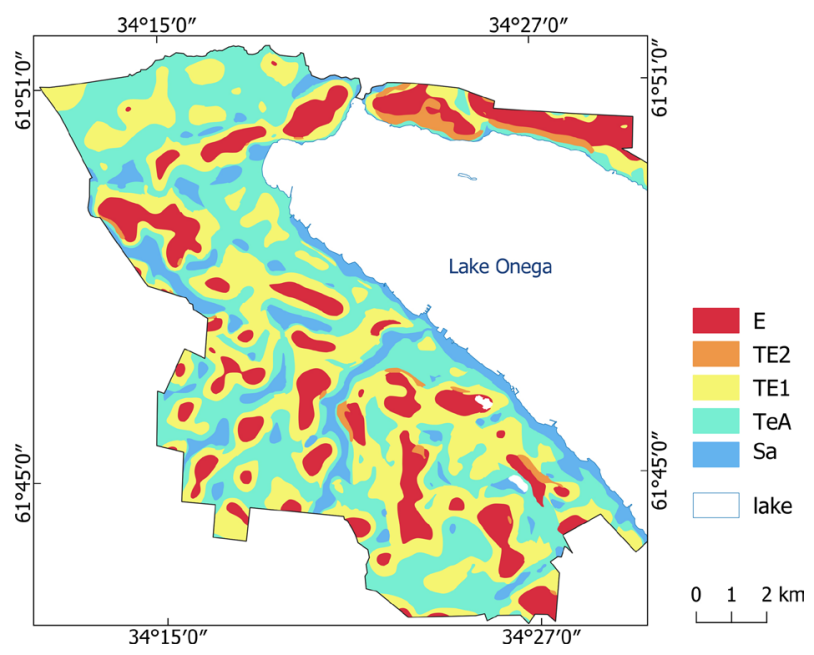

Fig. 8. Elementary landscapes. Decoding of indices in Table 2. 
Table 2. Criteria for distinguishing elementary landscapes.

\begin{tabular}{|c|c|c|c|c|c|}
\hline \multirow{2}{*}{$\begin{array}{l}\text { Elementary } \\
\text { landscapes }\end{array}$} & \multirow{2}{*}{ Index } & \multirow{2}{*}{ Landforms } & \multicolumn{3}{|c|}{ Morphometric parameters } \\
\hline & & & TPI & Slope & Curvature \\
\hline \multirow[t]{2}{*}{ Eluvial } & \multirow[t]{2}{*}{$\mathrm{E}$} & \multirow{2}{*}{$\begin{array}{l}\text { Flat watershed surfaces } \\
\text { Convex tops of hills and ridges } \\
\text { Above the floodplain terrace, clearly expressed in relief }\end{array}$} & $>1 S D$ & $<5$ & $0,+$ \\
\hline & & & $>1 S D$ & $3-10$ & + \\
\hline $\begin{array}{l}\text { Transeluvial } \\
\text { (moderate offset) }\end{array}$ & TE2 & Slopes of medium steepness & $\begin{array}{l}-1 S D \\
1 S D \\
<-1 S D\end{array}$ & $5-10$ & $\begin{array}{c}-, 0,+ \\
0,+\end{array}$ \\
\hline $\begin{array}{l}\text { Transeluvial } \\
\text { (low offset) }\end{array}$ & TE1 & Gentle slopes & $\begin{array}{l}-1 \text { SD -0 } \\
0-1 S D\end{array}$ & $<5$ & $\begin{array}{c}0,+ \\
-, 0,+\end{array}$ \\
\hline $\begin{array}{l}\text { Transeluvial- } \\
\text { accumulative }\end{array}$ & TeA & The foot of the slope & $\begin{array}{l}-1 S D-0 \\
<-1 S D\end{array}$ & $\begin{array}{l}<3 \\
2-5 \\
<5 \\
5-10\end{array}$ & $\begin{array}{c}-, 0 \\
- \\
0,+ \\
-\end{array}$ \\
\hline Super-aquatic & $\mathrm{Sa}$ & Depressions and ravines, floodplains & $<-1 S D$ & $<3$ & - \\
\hline
\end{tabular}

of the slopes reflects the areas of accumulation and washout of the substance. Positive values of curvature are typical for inclining slopes and occupy about $10 \%$ of the territory. Concave areas with negative curvature, characterised by accumulation, are developed in drainage lowlands, depressions and basins (Fig. 7).

Combinations of morphometric parameters make it possible to distinguish elementary landscapes. A method has been developed to identify elementary landscapes by morphometric features: location, slope and curvature (Table 2). Based on the results obtained, a map of elementary landscapes of Petrozavodsk was compiled, taking into account the migration of matter (Fig. 8). There are five types of terrestrial landscapes on the territory of the city. Transeluvial-accumulative landscapes $(35.7 \%)$ and transeluvial landscapes with low removal $(33.7 \%)$ are predominantly Karelian.

\section{Quaternary deposits}

The study of the lithogenic base is important in landscape studies since it largely determines the processes of the geosystem functioning. The composition of the Quaternary deposits represented within the city is closely related to the history of geological development. In the Late Valdai time, the study area was influenced by a glacier that covered the area with powerful moving continental ice (Lake Onega 2010). In the course of its movement, vast glacial plains were formed, composed of moraines - rubbly sandy loam, sands, loams. In the late-glacial period, in the basin of Lake Onega and on the adjacent lowlands, a large periglacial reservoir was formed, the deposits of which are of ribbon clays and silts that compose lacustrine-glacial plains, as well as sandy terraces. The retreat of the glacier is accompanied by a gradual drop in the lake level and the formation of lake terraces. Thus, within the city limits, three genetic types of Quaternary deposits are identified: moraine, lacustrine-glacial and lacustrine. The boundaries of lacustrine and lacustrine-glacial facies are poorly recorded. In terms of lithological composition, moraine deposits are mainly represented by rubbly sandy loams, characterised by poor sorting of material. Moraine deposits are widespread in the eastern, south-eastern part of the city, starting from absolute elevations of $80-85 \mathrm{~m}$. The northern part of the city is composed of loamy-clayey deposits of lacustrine-glacial genesis. Sandy deposits of lacustrine and lacustrine-glacial genesis occur on the territory of the lower parts of the slopes adjacent to Lake Onega (Fig. 9).

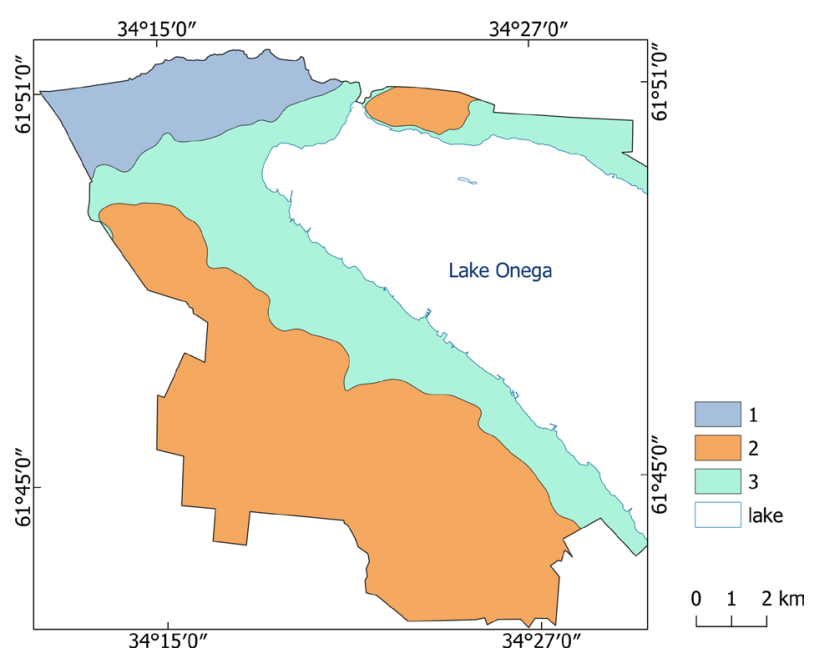

Fig. 9. Scheme of distribution of quaternary deposits 1 - loamy-clayey lacustrine-glacial deposits; 2 - moraine sandy loam; and 3 - sandy lacustrine-glacial and lacustrine deposits. 


\section{Functional organisation}

The functional organisation of the city's territory is shown in Figure 10. The largest industrial zones are identified in the northern part of the city. There are enterprises belonging to various types of industry, warehouses, road transport and repair shops, woodworking enterprises, metalworking and metal rolling enterprises are represented extensively. In the western part, there is an industrial zone formed by the Petrozavodsk CHPP. This facility is equipped with both high-altitude and surface emission sources. Enterprises of the auxiliary complex are located along the railway. Loading and unloading operations are carried out for transportation by rail. In the south-eastern part of the city, the largest sources of anthropogenic pressure are the shipbuilding plant, the Petrovsky distillery, as well as enterprises of the light and food industries, metalworking enterprises, etc. The area allotted for industrial areas is $14 \%$ (Fig. 11). The predominant distribution of civil buildings in the city centre presupposes a significant development of the road network. The problem of solving transport in the city is becoming quite urgent. Residential territories make up $27 \%$ of the area. Industrial and residential areas occupy almost the entire coastal slope. Agricultural land occupies less than 5\% of the territory and is located in the southern part of the city. A significant advantage of Petrozavodsk is the availability large number of green spaces. On three sides, the city is surrounded by forests that are surviving in natural conditions. There are many parks and forest parks within the city.

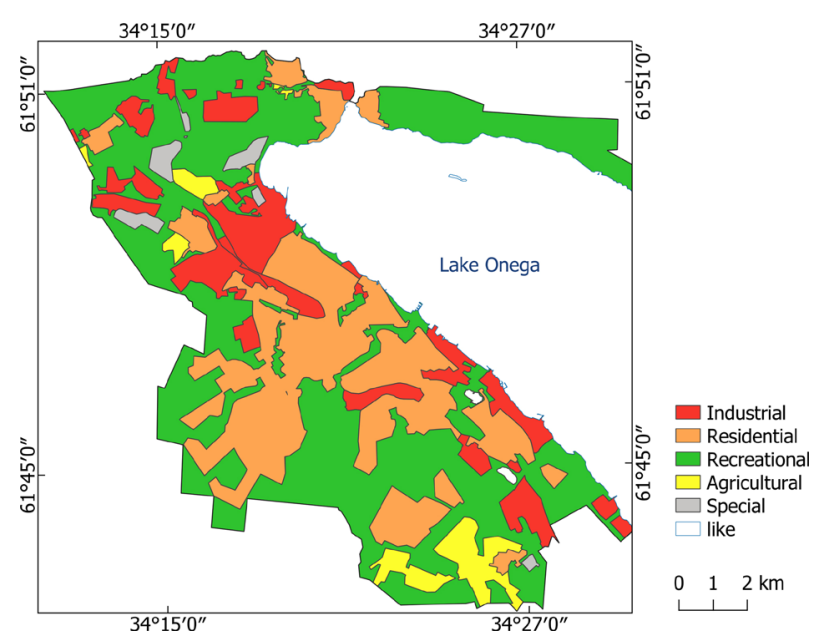

Fig. 10. Map of functional zoning.

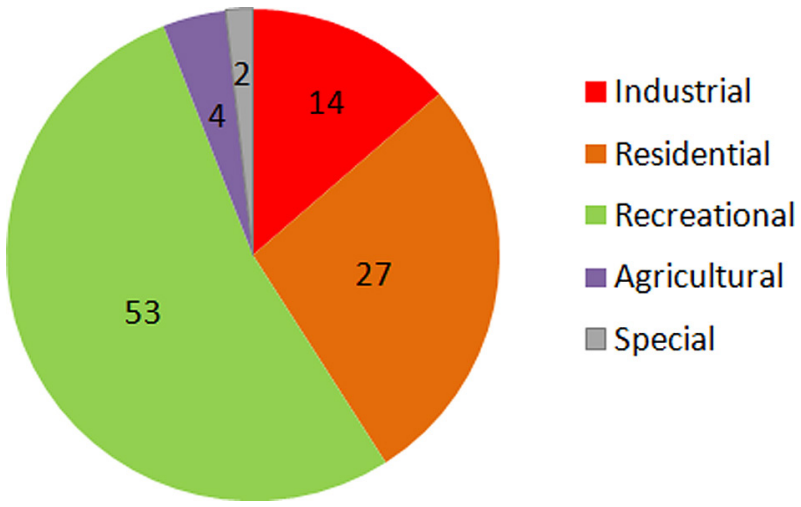

Fig. 11. Distribution of functional areas on the territory of Petrozavodsk.

Forests and forest parks occupy $53 \%$ of the territory. They constitute recreational potential of the city. The area of special zones is less than $2 \%$.

\section{Landscape modelling}

The landscape model is synthetic and created using overlay operations on the obtained thematic layers (Fig. 12). The model is generalised for a given scale $(1: 100,000)$.

The map legend is presented in the form of a matrix where elementary landscapes are shown in colour. The colour tone corresponds with the composition of the lithogenic base. The functional belonging of the territory is highlighted by shading.

Within thecity, 58categories of landscapes have been identified, characterised by a homogeneous geological composition, technogenic load and conditions for the migration of matter. The ratio of the area occupied by different landscape zones is shown in Figure 13. Generally, transelluvial landscapes with a low outflow (34\%) and transelluvial-accumulative $(36 \%)$ elementary landsca pes are the most widespread in the city. This determines the predominance of migration processes in the city. Eluvial landscapes dominate moraine deposits (12\%) located at a higher hypsometric level. The share of super-aquatic landscapes is $10 \%$.

Industrial zones are located mainly on trans-accumulative landscapes composed of lacustrine sands, as well as on transelluvial elementary landscapes composed of moraine and sandy deposits. Residential areas are mostly located on transeluvial and trans-accumulative landscapes. Recreational zones occupy a position in eluvial 


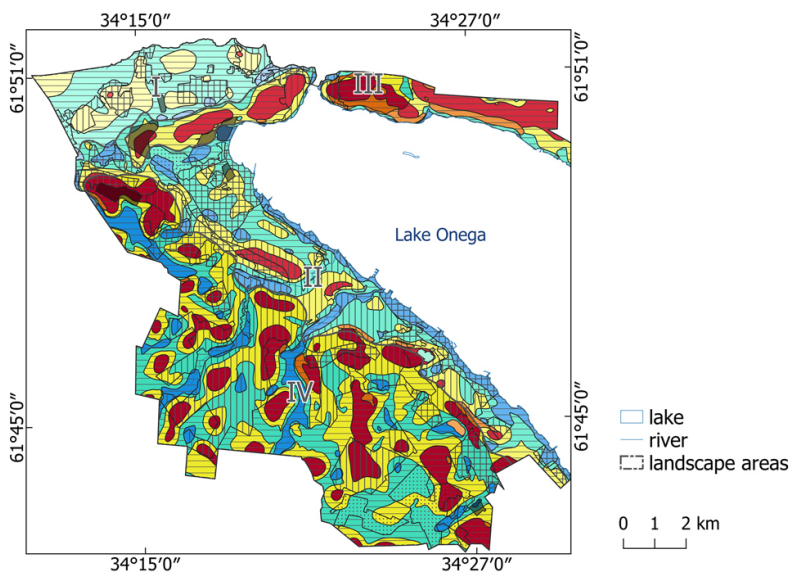

\begin{tabular}{|c|c|c|c|c|c|c|c|c|c|c|c|c|c|c|c|}
\hline \multirow{3}{*}{$\begin{array}{l}\text { Functional use } \\
\text { type }\end{array}$} & & \multicolumn{3}{|c|}{$\begin{array}{l}\text { Autonomous (eluvial) } \\
\text { E }\end{array}$} & \multicolumn{2}{|c|}{$\begin{array}{c}\text { Transelluvial } \\
\text { (moderate offset) }\end{array}$} & \multicolumn{3}{|c|}{$\begin{array}{c}\text { Transelluvial (low offset) } \\
\text { Te1 }\end{array}$} & \multicolumn{3}{|c|}{$\begin{array}{c}\text { Transeluvial-accumulative } \\
\text { TeA }\end{array}$} & \multicolumn{3}{|c|}{$\begin{array}{l}\text { Superaquatic } \\
\text { Sa }\end{array}$} \\
\hline & & $\begin{array}{l}\text { moraine } \\
\text { loam, silt }\end{array}$ & \begin{tabular}{|c|}
$\begin{array}{c}\text { lacustrine- } \\
\text { glacial clays } \\
\text { and silts }\end{array}$ \\
\end{tabular} & $\begin{array}{c}\text { lacustrine, } \\
\text { lacustrine- } \\
\text { glacial sands }\end{array}$ & $\begin{array}{l}\text { moraine } \\
\text { loam, silt }\end{array}$ & \begin{tabular}{|c|}
$\begin{array}{l}\text { lacustrine- } \\
\text { glacial clays } \\
\text { and silts }\end{array}$ \\
\end{tabular} & $\begin{array}{l}\text { moraine } \\
\text { loam, silt }\end{array}$ & $\begin{array}{c}\text { lacustrine- } \\
\text { glacial clays } \\
\text { and silts }\end{array}$ & $\begin{array}{c}\text { lacustrine, } \\
\text { lacustrine- } \\
\text { glacial sands }\end{array}$ & $\begin{array}{l}\text { moraine } \\
\text { loam, silt }\end{array}$ & $\begin{array}{c}\text { lacustrine- } \\
\text { glacial clays } \\
\text { and silts }\end{array}$ & $\begin{array}{c}\text { lacustrine, } \\
\text { lacustrine- } \\
\text { glacial sands }\end{array}$ & $\begin{array}{l}\text { moraine } \\
\text { loam, silt }\end{array}$ & $\begin{array}{c}\text { lacustrine- } \\
\text { glacial clays } \\
\text { and silts }\end{array}$ & \begin{tabular}{|c|} 
lacustrine, \\
lacustrine- \\
glacial sands \\
\end{tabular} \\
\hline & & $E_{1}$ & $E_{2}$ & $\mathrm{E}_{3}$ & $\mathrm{Te}_{1}$ & $\mathrm{Te}_{2}$ & $\mathrm{Te}_{1}$ & \begin{tabular}{|c|}
$\mathrm{Te}_{2}$ \\
\end{tabular} & $\mathrm{Te}_{3}$ & $\mathrm{TeA}_{1}$ & $\mathrm{TeA}_{2}$ & $\mathrm{TeA}_{3}$ & $S a_{1}$ & $\mathrm{Sa}_{2}$ & $\mathrm{Sa}_{3}$ \\
\hline Industrial & i & $E_{1}{ }^{\prime}$ & $E_{2}^{i}$ & $E_{3}$ & & $\mathrm{Te}_{2}$ & $\mathrm{Tel}_{1}^{\mathrm{i}}$ & $\mathrm{Te}_{2}$ & $\mathrm{Tel}_{3}{ }^{\mathrm{i}}$ & $\operatorname{TeA}_{1}{ }^{i}$ & $\mathrm{TeA}_{2}{ }^{\mathrm{i}}$ & $\mathrm{TeA}_{3}{ }^{\mathrm{i}}$ & $\mathrm{Sa}_{1}{ }^{\mathrm{i}}$ & $\mathrm{Sa}_{2}{ }^{\mathrm{i}}$ & $\mathrm{Sa}_{3}{ }^{\mathrm{i}}$ \\
\hline Residential & $r$ & $E_{1}^{r}$ & $E_{2}^{r}$ & & $\mathrm{Te}_{1}{ }^{\mathrm{r}}$ & $\mathrm{Te}_{2}{ }^{\mathrm{r}}$ & $\mathrm{Te}_{1}{ }^{\mathrm{r}}$ & $\mathrm{Te}_{2}{ }^{\mathrm{r}}$ & 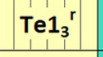 & $\mathrm{TeA}_{1}{ }^{\mathrm{r}}$ & $\mathrm{TeA}_{2}^{\mathrm{r}}$ & $\operatorname{TeA}_{3}{ }^{r}$ & $\mathrm{Sa}_{1}{ }^{\mathrm{r}}$ & $\mathrm{Sa}_{2}{ }^{i}$ & $\mathrm{Sa}_{3}{ }^{r}$ \\
\hline Recreational & $\mathrm{re}$ & $\mathrm{E}_{1}^{\mathrm{rc}}$ & $\mathrm{E}_{2}^{\mathrm{rc}}$ & $\mathrm{E}_{3}^{\mathrm{rc}}$ & $\mathrm{Te}_{1}{ }^{\mathrm{rc}}$ & $-\mathrm{Te}_{2}{ }^{\mathrm{rC}}$ & $\mathrm{Te}_{1}{ }_{1}^{\mathrm{rC}}$ & $\mathrm{Te}_{2}{ }^{\mathrm{rc}}$ & $\mathrm{Te}_{3}{ }^{\mathrm{rc}}$ & $\mathrm{TeA}_{1}{ }^{\mathrm{rc}}$ & $\mathrm{TeA}_{2}{ }^{\mathrm{rc}}$ & $\mathrm{TeA}_{3}{ }^{\mathrm{rc}}$ & $\mathrm{Sa}_{1}{ }^{\mathrm{rc}}$ & $\mathrm{Sa}_{2}{ }^{\mathrm{rc}}$ & $\mathrm{Sa}_{3}{ }^{\mathrm{rc}}$ \\
\hline Agricultural & a & $\mathrm{E}_{1}{ }^{\mathrm{a}}$ & $E_{2}{ }^{a}$ & & & & $\mathrm{Tel}_{1}^{\mathrm{a}}$ & $\mathrm{Te1}_{2}^{\mathrm{a}}$ & $\mathrm{Te1}_{3}^{\mathrm{a}}$ & $\mathrm{TeA}_{1}^{\mathrm{a}}$ & $\mathrm{TeA}_{2}^{\mathrm{a}}$ & $\mathrm{TeA}_{3}^{\mathrm{a}}$ & $\mathrm{Sa}_{1}{ }^{\mathrm{a}}$ & $\mathrm{Sa}_{2}$ & \\
\hline Special & s & $\mathrm{E}_{1}^{\mathbf{s}}$ & & & & & Te1 & $\mathrm{Te1}_{2}^{\mathrm{s}}$ & & $\mathrm{TeA}_{1}{ }^{\mathrm{s}}$ & $\mathrm{TeA}_{2}{ }^{\mathrm{s}}$ & $\mathrm{TeA}_{3}^{\mathrm{s}}$ & $\mathrm{Sa}_{1}{ }^{\mathrm{s}}$ & $\mathrm{Sa}_{2}^{\mathrm{s}}$ & \\
\hline
\end{tabular}

Fig. 12. Landscape model of Petrozavodsk.

Landscape areas: I - northern area; II - central area; III - western area; and IV - north-east area.
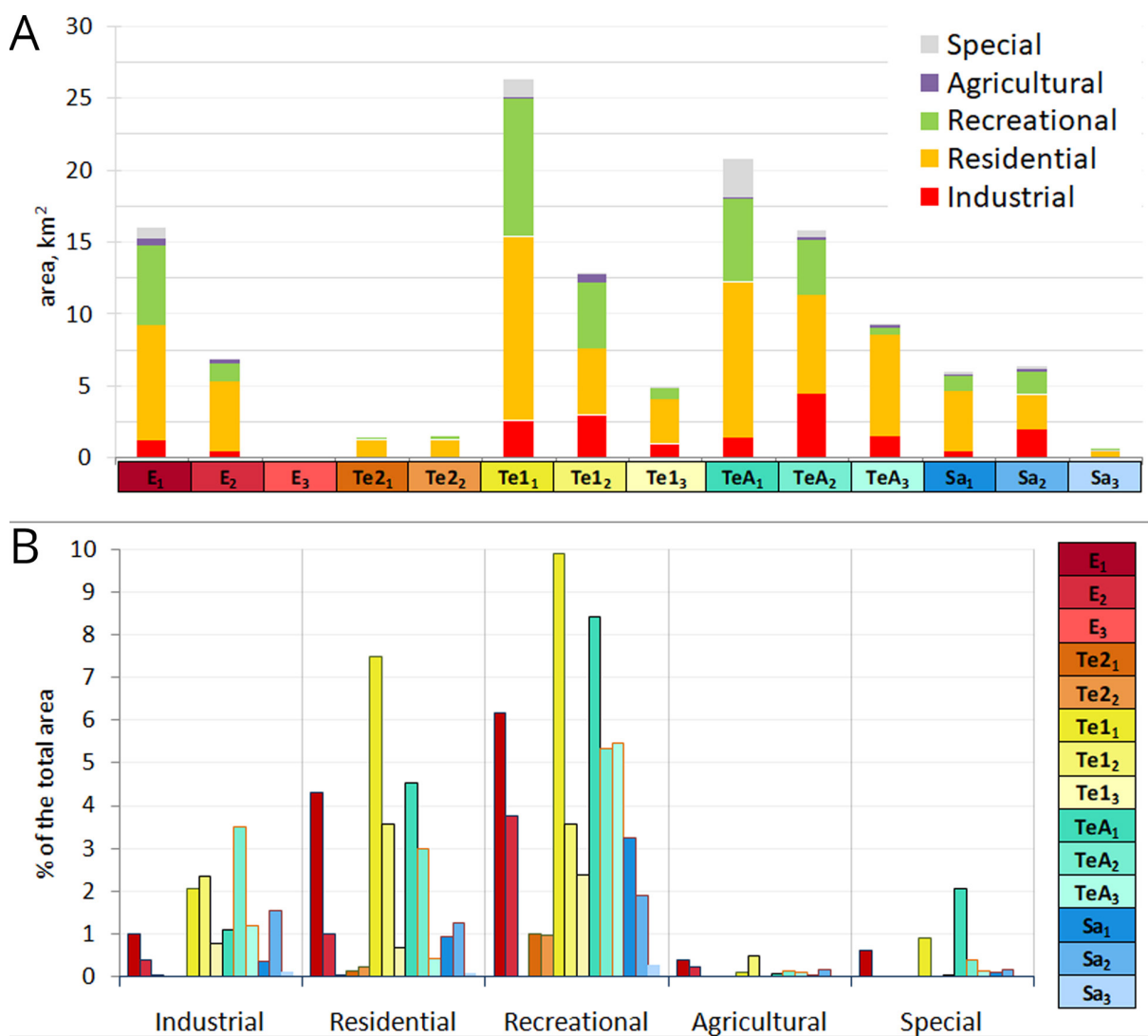

Fig. 13. The ratio of the area occupied by landscape zones. Decoding of indices in Figure 12. 
$(6 \%)$, and transeluvial (10\%) and transeluvial-accumulative $(9 \%)$ landscapes composed of moraine deposits.

The complex mechanism of migration within residential and industrial zones is due to the significant sealing of the soil cover. The greatest accumulation of substances is expected in super-aquatic elementary landscapes, composed of clay deposits in industrial and residential areas. Such territories occupy less than $1 \%$ of the territory. Also, special attention should be paid to industrial and residential areas on transeluvial-accumulative and super-aquatic elementary landscapes, which are composed of moraine deposits.

Based on the results, the landscape complexes are combined into four landscape areas:

- The northern area is an area of predominant distribution of transeluvial-accumulative landscapes on lacustrine sediments and a low technogenic load.

- The central area is distributed along the coastal slope. Transeluvial-accumulative and subaquatic landscapes on sandy and sandy-gravel deposits are developed here. Industrial and residential type of technogenic impact predominates.

- The western area is elevated, with a predominant distribution of autonomous landscapes and dominance of recreational and residential areas.

- North-east area is the area of distribution of transeluvial landscapes and the predominant development of recreational zones.

\section{Conclusions}

The work implements an integrated approach for visualising the landscape structure based on data from a digital elevation model, geological data, and data on technogenic load.

Using the TPI parameter in determining locations allows to distinguish different landforms confidently, from uplands to valleys. The highlighted relief elements correspond to the basic units of the positional structure of landscapes. Landscape units are determined based on morphometric data: location, slope and curvature. The detail of the source data determines the scale of the resulting model.
Modelling the structure of terrestrial landscapes contributes to understanding the landscape and technogenic features of an urban area. The developed legend of the terrestrial landscape model is a matrix that reflects data on the elementary landscape, the composition of the constituent rocks and the technogenic impact. The analysis of the model gives an idea of the external and internal factors of the formation of the geosystem and shows the ways of lateral migration of matter.

The study of the landscapes revealed that the processes of migration in the city prevail over the processes of accumulation. Four landscape regions have been identified within Petrozavodsk according to the prevailing distribution of landscape complexes. So, when assessing environmental risk within an urban area, it will be useful and better if the landscape structure is taken into account.

\section{Acknowledgements}

The study was carried out according to the program of the Institute of Geology of the Karelian Research Center AAAA-A18-118020690231-1. The authors thank the reviewers for their remarks and comments on the work.

\section{References}

De Ferranti J., 2014. Digital elevation data. Online: http:// viewfinderpanoramas.org/dem3.html (accessed 15 December 2020).

De Reu J., Bourgeois J., Bats M., Zwertvaegher A., Gelorini V., De Smedt Ph., Chu W., Antrop M., De Maeyer Ph., Finke P., Van Meirvenne M., Verniers J., Crombé Ph., 2013. Application of the topographic position index to heterogeneous landscapes. Geomorphology 186: 39-49. DOI 10.1016/j.geomorph.2012.12.015.

Drăgut L., Blaschke T., 2006. Automated classification of landform elements using object-based image analysis. Geomorphology 81(3-4): 330-344. DOI 10.1016/j.geomorph.2006.04.013.

Evans I. S., 2012. Geomorphometry and landform mapping: What is a landform? Geomorphology 137(1): 94-106. DOI 10.1016/j.geomorph.2010.09.029.

Florinsky I.V., 2012 Morphometric variables. In: Digital terrain analysis in soil science and geology. 7-30. DOI 10.1016/ b978-0-12-385036-2.00002-x.

Gallant J.C., Wilson J.P., 2000. Primary topographic attributes. In: Wilson J.P., Gallant, J.C. (eds), Terrain analysis: Principles and applications. Wiley, New York: 51-85.

Glazovskaya M.A., 1988. Geochemistry of natural and technogenic landscapes of the USSR, High school, Moscow: 327.

Jones K.L., Poole G.C., O'Daniel S.J., Mertes L.A.K., Stanford J., 2008. Surface hydrology of low-relief landscapes: As- 
sessing surface water flow impedance using LIDAR-derived digital elevation models. Remote Sensing of Environment 112(11): 4148-4158. DOI 10.1016/j.rse.2008.01.024.

Klingseisen B., Metternicht G., Paulus G., 2008. Geomorphometric landscape analysis using a semi-automated GIS-approach. Environmental Modelling and Software 23(1): 109-121. DOI 10.1016/j.envsoft.2007.05.007.

Krenke A.N., Puzachenko Yu. G., 2008. Construction of a map of the landscape cover based on remote sensing information. Environmental Planning and Management 2: 10-26.

Krutskikh N.V., Borodulina G.S., Kaznina N.M., Batova Yu., Ryazantsev P.A., Akhmetova G.V., Novikov S.G., Kravchenko I.Yu., 2016. Geoecological basis for setting up the monitoring of urbanized areas in the north (the example of Petrozavodsk). Works of the Karelian Scientific Center of the RAS 12: 52-67.

Krutskikh N.V., Kosinova I.I., 2014. Methodology division of urban areas according to ecological-geochemical studies (on example of city Petrozavodsk). Bulletin of Voronezh State University. Geology 3: 95-97.

Lake Onega. Atlas. 2010. Filatov N.N. (ed.), KarRC RAS, Petrozavodsk: 151

Mkrtchyan A.S., 2006. Automated selection of landscape units by classification of relief using GIS. In: Dobrolyubov S.A. (ed), Landscape Planning: General Foundations, Methodology, Technology, MSU, Moscow: 203-208.

Mokarram M., Seif A., 2014. GIS-based automated landform classification in Zagros mountain (case study: Grain mountain). Bulletin of Environment, Pharmacology and Life Sciences 3(3): 20-32.

Novakovsky B.A., Krasovskaja T.M., Tulskaja N.I., 2007. Use of digital modeling of the relief and remote sounding for actualization of small-scale landscape and ecological maps of mountain areas. Geoinformatics 4: 3-8.

Novakovsky B.A., Permyakov R.V., 2019. Integrated geoinformation and photogrammetric modeling of the relief, MIIGAiK, Moscow: 175.

Novikov S.G., 2015. Assessment of heavy metal contamination in soils of different land use types in Petrozavodsk. Works of the Karelian Scientific Center of the RAS 1: 78-85.

Piloyan A., Konečný M., 2017. Semi-automated classification of landform elements in Armenia based on SRTM DEM using K-means unsupervised classification. Quaestiones Geographicae 36(1): 93-103. DOI 10.1515/quageo-2017-0007.
Planchon O., Darboux F., 2002. A fast, simple and versatile algorithm to fill the depressions of digital elevation models. Catena 46(2-3): 159-176.

Polynov B.B., 1952. Geographic works. Geografgiz, Moscow: 400.

Quaternary deposits of Finland and the North-West of the Russian Federation and their mineral resources. Scale 1:1,000,000. 1993. Niemelä J., Ekman I., Lukashev A. (eds), Geological Survey of Finland, Kar. Scientific Center RAS, Helsinki.

Shary P., Sharaya L., Mitusov A., 2002. Fundamental quantitative methods of land surface analysis. Geoderma 107(12): $1-32$.

Sokolov S.V., Yurchenko Yu.Yu., 2010. Digital elevation model as the basis for regionalization of territories according to the conditions of conducting geochemical works (on the example of the Small Khingan, Far East). Geoinformatics 4: 54-60.

Szypuła B., 2019. Quality assessment of DEM derived from topographic maps for geomorphometric purposes. Open Geosciences 11(1): 843-865. DOI 10.1515/geo-2019-0066.

Tagil S., Jenness J., 2008. GIS-Based automated landform classification and topographic, landcover and geologic attributes of landforms around the Yazoren Polje, Turkey. Journal of Applied Sciences 8(6): 910-921. DOI 10.3923/ jas.2008.910.921.

Tokarev S.V., Roshchina K.N., 2015 Mapping elements of the earth's surface relief using the index of the topographic position (on the example of the Crimean Peninsula). Scientific Notes of the Crimean Federal University. Geography. Geology 1(67): 64-85.

Vlasov D.V., Kasimov N.S., Kosheleva N.E., 2017. Mapping of landscape and geochemical structure of urban territory (Moscow case study). InterCarto/InterGIS 1(23): 242255. DOI 10.24057/2414-9179-2017-1-23-242-255

Weiss A.D., 2001. Topographic position and landforms analysis, poster presentation. In: ESRI User Conference, San Diego. Online: www.jennessent.com/downloads/TPIposter-TNC_18x22.pdf (accessed 15 December 2020).

Zhuchkova V.K., Rakovskaya E.M., 2004. Methods of complex physical and geographical research. Academy, Moscow: 368.

Zwoliński Zb., Stefańska E., 2015. Relevance of moving window size in landform classification by TPI. In: Jasiewicz J., Zwoliński Zb., Mitasova H., Hengl T., (eds), Geomorphometry for Geosciences, Bogucki Wydawnictwo Naukowe, Poznań: 273-277. 